\title{
Identifikasi Pertumbuhan Sayuran dengan Ikan Nila (Oreochromis niloticus) Menggunakan Akuaponik Sistem Apung
}

\author{
Abas U. Saleh ${ }^{1)}$, Ikrima Staddal ${ }^{2}$, Sjahril Botutihe ${ }^{3)}$ \\ 1,2,3) Program Studi Mesin dan Peralatan Pertanian, Politeknik Gorontalo \\ Jl. Muchlis Rahim, Desa Ponggulo Barat, Kec. Botupingge, Kab. Bone Bolango, Gorontalo, Indonesia \\ e-mail: abassaleh35@gmail.com
}

\begin{abstract}
ABSTRAK
Akuaponik adalah penggabungan antara budidaya ikan dan hidroponik (budidaya tumbuhan). Akuaponik menjadi salah satu solusi beternak sekaligus menanam di perkotaan dengan menngunakan lahan sempit. Dalam budidaya ikan nila tentunya menghasilkan limbah air kolam yang bersal dari metabolisme ikan dan sisa pakan yang terlarut. Air yang berasal dari limbah ikan nila ini masih bisa digunakan untuk proses pembudidayaan sayuran melalui sistem akuaponik. Penelitian ini dilakukan dengan tujuan untuk mengetahui pengaruh limbah kolam ikan nila terhadap pertumbuhan sayuran yang mennggunakan sistem apung untuk peningkatan kapasitas produksi. Penelitian ini dilakukan di green house Program Studi Mesin dan Pralatan Pertanian Politeknik Gorontalo. Penelitian dilakukan pada tiga perlakuan masing-masing dengan jumlah sayuran sebanyak 25 tanaman. Tiga jenis sayuran yang menjadi objek penelitian adalah kangkung, pakcoy, dan bayam. Variabel penelitian meliputi tinggi tanaman, jumlah daun, lebar daun, panjang daun, dan diameter batang. Hasil penelitian dianalisis dari minggu pertama sampai minggu keempat. Hasil penelitian menunjukan bahwa metode aquaponik sistem apung merupakan metode yang baik untuk budi daya sayur-sayuran, terutama kangkung tanpa tambahan AB MIX.
\end{abstract}

Kata Kunci: akuaponik, sayuran, sistem apung, ikan nila

\begin{abstract}
Aquaponics is a combination of fish farming and hydroponics (plant cultivation). Aquaponics is a solution for raising livestock as well as planting in urban areas using narrow land. In tilapia cultivation, of course, it produces pond water waste that comes from fish metabolism and dissolved feed residue. The water that comes from tilapia waste can still be used for the process of cultivating vegetables through the aquaponics system. This research was conducted with the aim of knowing the effect of tilapia pond waste on the growth of vegetables using a floating system to increase production capacity. This research was conducted at the Greenhouse of the Agricultural Machinery and Equipment Study Program of the Politeknik Gorontalo. The study was conducted on three treatments each with the number of vegetables as many as 25 plants. Three types of vegetables that became the object of research were kale, pakcoy, and spinach. The research variables included plant height, number of leaves, leaf width, leaf length, and stem diameter. The results of the study were analyzed from the first week to the fourth week. The results showed that the floating system aquaponics method is a good method for cultivating vegetables, especially kale without the addition of AB MIX.
\end{abstract}

Keywords: aquaponics, vegetables, floating system, tilapia fish 


\section{PENDAHULUAN}

Akuaponik merupakan salah satu teknologi yang digunakan untuk membudidayakan tanaman sayuran dengan ikan. Sistem akuaponik saat ini semakin berkembang tidak hanya pada skala rumah tangga tetapi sudah sampai pada skala industri. Akuaponik yang ada sampai saat ini telah mengalami banyak perkembangan model yang didasari dari sistem hidroponik, mulai dari sistem apung, sistem NFT sampai sistem DFT.

Teknologi akuaponik memiliki keuntungan ekonomis berupa pemasukan tambahan dari hasil tanaman yang akan memperbesar keuntungan para petani sayuran dan peternak ikan. Apabila dibandingkan dengan budidaya konvensional berbasis tanah, terdapat beberapa keunggulan akuaponik diantaranya adalah tidak memerlukan pupuk dan dapat dilakukan pada lahan non pertanian. Hasil dari teknologi ini terdiri dari dua produk sekaligus yakni tanaman dan ikan dengan terkategori organik. Selain itu, menghemat tenaga kerja dan dapat dilakukan oleh setiap orang pada berbagai lapisan masyarakat.

Kebutuhan hasil pertanian semakin meningkat seiring jumlah kebutuhan penduduk, telah menggeser banyak lahan pertanian yang semakin terbatas. Akuaponik merupakan salah satu alternatif yang digunakan untuk membudidayakan tanaman pertanian terutama didaerah perkotaan yang sempit. Sistem akuaponik ini dimanfaatkan sebagai tempat media budidaya sayuran dan budidaya ikan. Pemilihan komuditas untuk sistem akuaponik, memegang peranan penting dalam memecahkan dan mendaptkan hasil yang sesuai denganapa yang di inginkan. Jenis tanaman yang dapat dibudidayakan pada sistem akuaponik, antara lain bayam, kangkung, sawih, selada, dan packoy. Sedangkan ikan yang bisa di gunakan yaitu nila, mas, koi, lele dan udang galah (Roidah, 2014).

Pada penelitian ini jenis tanaman yang digunakan antara lain kangkung, packoy, dan bayam. Penggunaan tanaman tersebut dikarenakan memiliki nilai ekonomis dan kandungan gizi yang cukup tinggi, dan mudah dibudidayakan. Kangkung memiliki kandungan gizi yang lengkap, diantaranya protein, lemak, karbohidrat, serat, kalsium, fosfor, zat besi, natrium, kalium, vitamin A, B, C dan karoten (Pracaya dalam Budiati, 2017). Selain itu, kangkung memiliki pertumbuhan yang mudah karena ia dapat tumbuh pada daerah yang beriklim panas dan dingin (Hidayat, 2019). Sebagaimana kangkung, pakcoy dan bayam juga memiliki kandungan gizi yang cukup tinggi dan memiliki manfaat yang banyak, baik dari segi kesehatan maupun dari segi ekonomi. Daun bayam dapat dimanfaatkan dalam pembuatan kripik yang gurih dan renyah (Tafajani, 2011). Kedua jenis sayuran ini umumnya dapat tumbuh pada kondisi derajat keasaman yang netral atau mendekati netral seperti pH 5-7 (Setiawan, 2014). Adapun jenis ikan yang digunakan umumnya adalah ikan nila. Hal ini karena nila dapat hidup di air tawar maupun air payau (Suyanto, 2010) dan memiliki toleransi yang tinggi terhadap lingkungan hidupnya (Khairuman \& Amri, 2013).

Pengembagan usaha budidaya sayuran dan ikan sistem akuaponik ini dipandang menguntungkan terkait dengan teresedianya sayuran sehat dan terhindar dari bahan kimia. Penggunaan sistem akuaponik guna melihat perkembangan ikan dan sayuran yang dibudidayakan secara bersamaan perlu dilakukan. Hal ini sangat berguna untuk mengetahui apa saja masalah dan kendala dengan cara budidaya seperti ini. Hal ini yang melatar belakangi penelitian dengan sistem akuaponik dilakukan. Pada penelitian ini aquaponik yang diterapkan menggunakan sistem apung. Sistem ini memiliki cara kerja yaitu tanaman ditempatkan dan dibesarkan dilubang styrofoam atau pipa PVC (Habiburrahman, 2018). Posisi styrofoam menggantung sehingga ada jarak antara permukaan air dengan pangkal akar (Gambar 1).

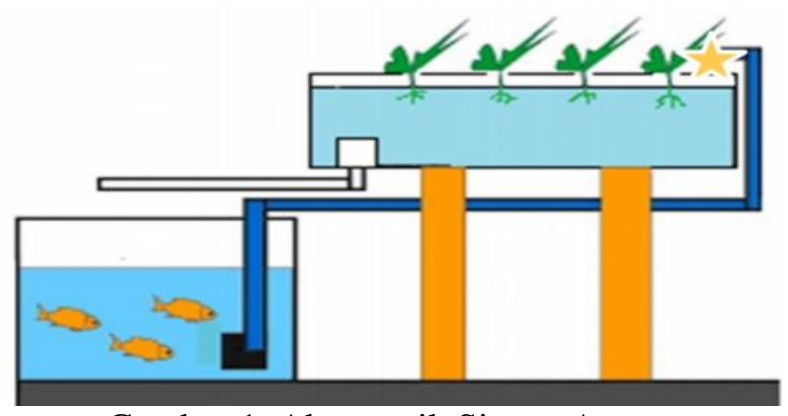

Gambar 1. Akuaponik Sistem Apung

Hasil penilitian ini diharapkan dapat memberikan contoh atau menggerakan para petani didaerah Gorontalo, untuk membudidayakan tanaman sayuran dan budidaya ikan sistem akuaponik. Pengembangan usaha budidaya tanaman sayuran dan budidaya ikan ikan sistem akuaponik, diharapkan mampu mencetak pengusaha-pengusaha di bidang budidaya pertanian dan perikanan. Selain itu, sistem akuaponik dapat diaplikasikan pada lahan-lahan sempit seperti di daerah perkotaan yang umumnya tidak tepat untuk bercocok tanam karena tanah yang tidak subur. 


\section{METODE PENELITIAN}

Penelitian ini merupakan penelitian kuantitatif dengan objek data adalah pertumbuhan tanaman meliputi tinggi tanaman, jumlah daun, lebar daun, panjang daun, dan diameter batang. Penelitian ini dilakukan mengikuti tahapan-tahapan sebagaimana disajikan dalam diagram alir pada Gambar 2.

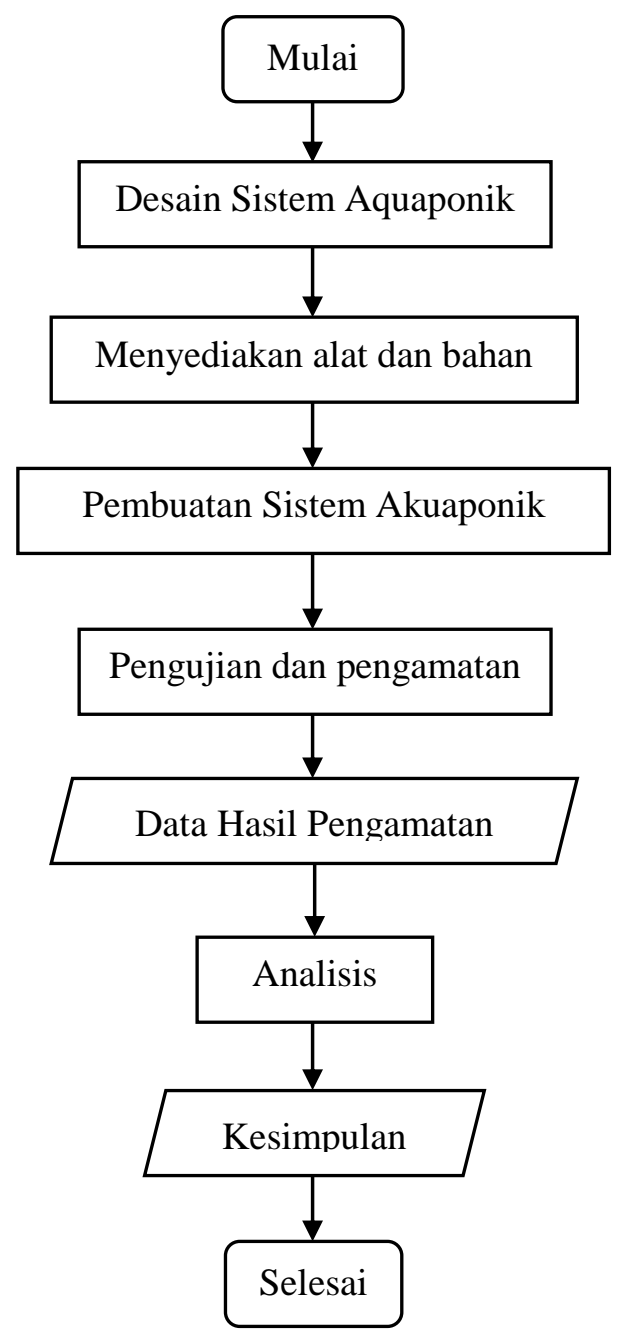

Gambar 2. Diagram Alir Penelitian

\section{Pembuatan Sistem Akuaponik}

Pembuatan sistem aquponik dilakukan dengan langkah-langkah sebagai berikut:

1. Menyiapkan besi siku $3 \mathrm{~mm}$ dengan panjang $3850 \mathrm{~mm}$.

2. Memotong besi siku masing-masing menjadi $1000 \mathrm{~mm}, 500 \mathrm{~mm}$, dan $250 \mathrm{~mm}$.

3. Memasang akuarium pada rak akuarium.

4. Mengisi akuarium dengan air sampai batas $3 / 4$ dari akuarium
5. Memotong stryfoam dipotong membentuk kotak, kemudian dilubangi dengan diameter 4,5 $\mathrm{cm}$ dengan jarak $5,5 \mathrm{~cm}$.

6. Netpot dipasang pada styrfoam.

7. Memotong rok wool dengan gergaji besi menjadi 81 bagian dengan ukuran $30 \mathrm{~mm}$.

8. Membuat lubang pada rockwool dengan kedalaman $5 \mathrm{~mm}$

9. Menggunting kain planel menjadi beberapa bagian.

10. Memasang kain planel pada netpot.

11. Memasang netpot pada stryfoam.

12. Memasang styrfoam pada akuarium.

13. Memasang pompa kedalam akuarium yang sudah diisi air.

\section{Penyemaian Benih Sayuran}

Persemaian dilakukan dengan menaburkan benih kangkung, packoy, dan bayam di dalam wadah persemaian yang berisi bak rockwool. Pemeliharaan bibit dilakukan sampai benih sayuran menunjukkan 3-4 daun. Setelah itu pandahkan benih yang sudah berumur 7-10 hari, kedalam sistem akuaponik yang berisi stryfoam, netpot, dan kain planel.

\section{Pembenihan Ikan}

Pembenihan ikan dilakukan pada saat persemaian pada tanaman sayuran telah terjadi, benih ikan yang dimasukan adalah ikan yang berumur 35 hari sebanyak 30 ekor, ikan harus dibatasi karena disesuaikan dengan ukuran akuarium yaitu $100 \times 50 \mathrm{~cm}$.

\section{Penanaman pada Sistem Aquoponik}

Penanaman dilakukan dengan langkah-langkah sebagai berikut:

1. Bibit tumbuh dan berdaun 3-4 helai (umur 7 hari), bibit diangkat dari bak persemaian dengan hati-hati.

2. Bibit diletakan pada netpot kemudian diletakan pada lubang stryfoam.

3. Akar tanaman diletakkan tegak lurus dengan lubang styrofoam sehingga akar berada pada chamber lingkungan tertutup tempat tumbuhnya akar.

4. Penanaman bibit dilakukan dengan 4 kelompok bagian sesuai dengan pemberian larutan nutrisi masing-masing. 


\section{Pemeliharaan}

Pemeliharaan tanaman dilakukan dengan langkah-langkah sebagai berikut:

1. Setelah ikan dimasukan kekolam, bibit sayuran selanjutnya dilakukan pemeliharaan.

2. Pemberian nutrisi berupa $\mathrm{AB}$ Mix tidak diberikan melainkan digantikan dari kotoran ikan.

3. Selanjutnya melakukan pemeliharaan dengan melihat tingkat $\mathrm{pH}$ dan $\mathrm{Ppm}$ pada air akuarium.

4. Larutan nutrisi disirkulasikan dengan pompa membentuk pusaran.

5. Setelah mendapat kanarus yang cukup kuat itu maka akan membentuk arus balik selanjutnya yang berlangsung terus menerus.

\section{Analisis Data}

Analisis data dilakukan dengan mengamati perkembangan dari tanaman sayuran dan ikan nila. Pada penelitian ini jenis tanaman yang digunakan antara lain kangkung, packoy, dan bayam. Penggunaan tanaman tersebut dikarenakan memiliki nilai ekonomis yang cukup tinggi, dan mudah dibudidayakan. Dan jenis ikan yang cocok digunakan yaitu ikan nila. Pengembagan usaha budidaya sayuran dan ikan sistem akuaponik ini dipandang menguntungkan terkait dengan tersedianya sayuran sehat dan terhindar dari bahan kimia.

\section{HASIL DAN PEMBAHASAN}

Secara umum, pertumbuhan sayur kangkung (Gambar 3.a) terlihat lebih cepat dan lebih baik dibandingkan sayur pakcoy dan sayur bayam (Gambar 3.b dan 3.c). Hal ini dapat disebabkan karena pada awal budidaya ikan nila dimungkinkan kotoran ikan dan sisa pakan masih belum terdekomposisi dengan sempurna, sehingga akan menganggu pertumbuhan tanaman.

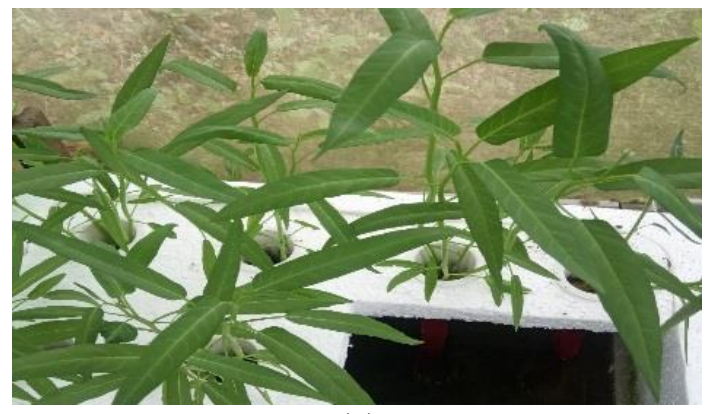

(a)

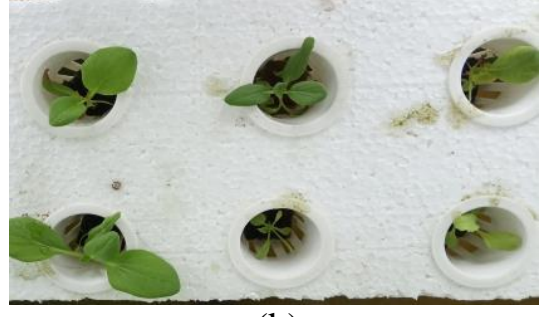

(b)

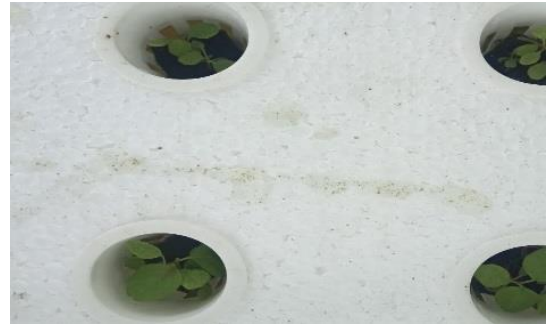

(c)

Gambar 3. Perbedaan Pertumbuhan untuk Tiga Jenis Sayur: (a) kangkung, (b) pakcoy, dan (c) bayam

\section{Pertumbuhan Sayuran Sistem Akuaponik}

Pengamatan pertumbuhan sayuran dilihat dari beberapa indikator seperti tinggi tanaman, diameter batang, lebar daun, panjang daun, dan jumlah daun. 1. Tinggi tanaman

Pada penelitian ini di lakukan pengukuran tinggi tanaman sayuran sebanyak 4 kali, yaitu pada minggu ke-1, ke-2, ke-3, dan ke-4. Tinggi tanaman selalu terus meningkat pada setiap minggunya pada pengukuran minggu ke-4. Tanaman kangkung menunujukan hasil lebih tinggi yaitu sebesar $39 \mathrm{~cm}$, tanaman pakcoy menununjukan hasil tinggi yaitu sebesar $5,1 \mathrm{~cm}$ sedangkan tanaman bayam menunjukan hasil tinggi yaitu $2,8 \mathrm{~cm}$ pada sistem akuaponik. Hasil rata-rata tinggi tanaman dapat dilihat pada Gambar 4.

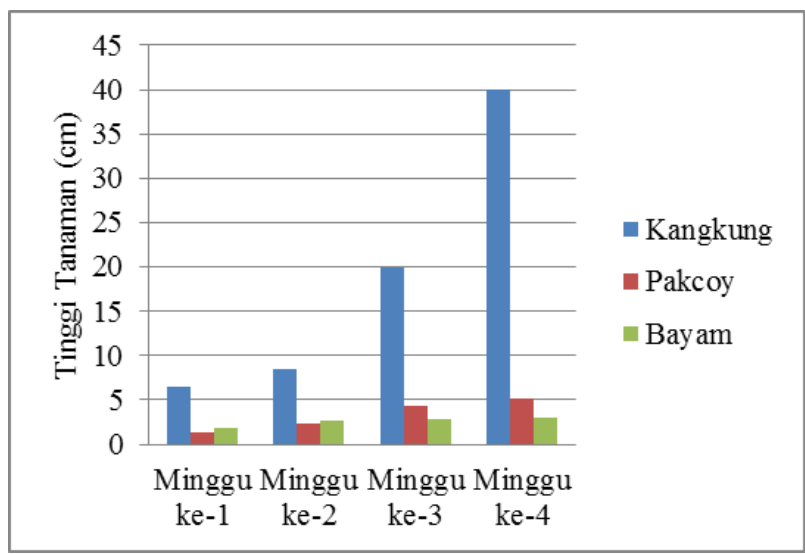

Gambar 4. Tinggi Tanaman untuk Tiga Jenis Sayuran 
Pada minggu pertama dan minggu kedua tinggi tanaman bayam dan pakcoy tidak memiliki perbedaaan yang signifikan. Adapun pada minggu ketiga dan keempat, tanaman pakcoy lebih tinggi dibandingkan bayam. Hal ini tentu berbeda jauh dengan kangkung yang pada minggu keempat memiliki tinggi $40 \mathrm{~cm}$. Peningkatan tinggi tanaman pada minggu keempat merupakan hasil dari pemberian dosis pupuk yang lebih tinggi dari kotoran ikan. Pertumbuhan tinggi tanaman dipengaruhi oleh kandungan nitrogen dan fosfat dalam formulasi larutan nutrisi yang diberikan. Ketersediaan nitrogen bagi tanaman dapat merangsang pertumbuhan secara keseluruhan khususnya batang, cabang dan daun karena nitrogen berfungsi sebagai bahan dasar sintesis asam amino, nukleid, klorofil dan protein (Furoidah \& Wahyuni, 2017)

\section{Diameter batang}

Pengukuran diameter batang sayuran dilakukan sebanyak 4 kali, yiatu pada minggu ke-1, ke-2, ke-3, dan ke-4. Diameter batang tanaman terus meningkat setiap minggunya. Nilai diameter batang untuk masing-masing sayuran pada minggu keempat yaitu $0,66 \mathrm{~cm}$ untuk kangkung, pakcoy $0,38 \mathrm{~cm}$, dan bayam 0,21 cm (Gambar 5).

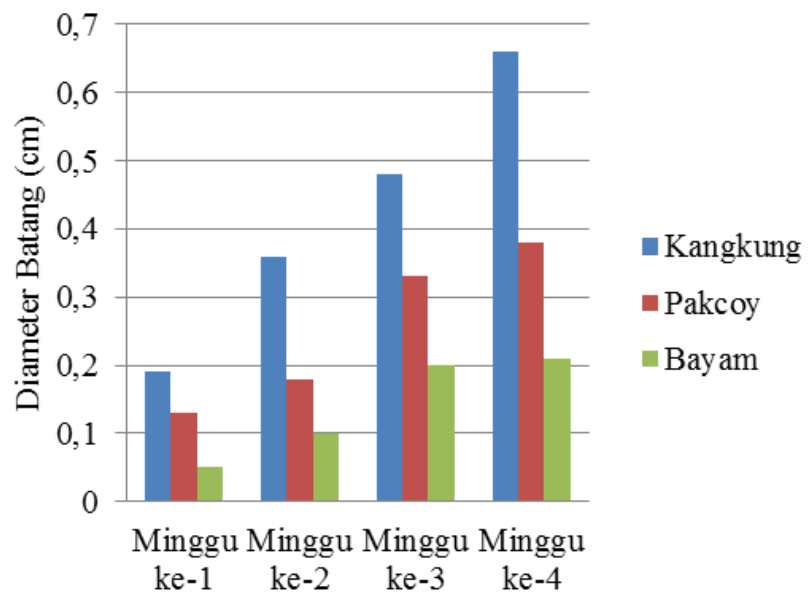

Gambar 5. Perkembangan Diamater Batang untuk Tiga Jenis Sayuran

\section{Lebar daun}

Pada sayur-sayuran, lebar daun menjadi indikator visual yang dapat menggambarkan kualitas produksi tanaman. Pengukuran pada minggu pertama dan kedua kangkung, pakcoy, dan bayam masing-masing memiliki lebar daun berkisar 0,310,63 cm, 0,81 -0,98 dan 0,13- 0,43 cm (Gambar 6). Pada minggu ketiga dilakukan pemberian nutrisi $\mathrm{Ab}$ mix sehingga sayur kankung memiliki lebar daun $1,28 \mathrm{~cm}$. Peningkatan ini terjadi karena pemberian nutrisi dapat meningkatkan kadar nitrogen yang dibutuhkan tanaman untuk pertumbuhanya. Laju pertumbuhan tanaman cenderung meningkat jika unsur hara yang dibutuhkan tanaman cukup tersedia dan dapat segera dimanfaatkan oleh tanaman, seperti halnya nitorogen (Sarido \& Junia, 2017).

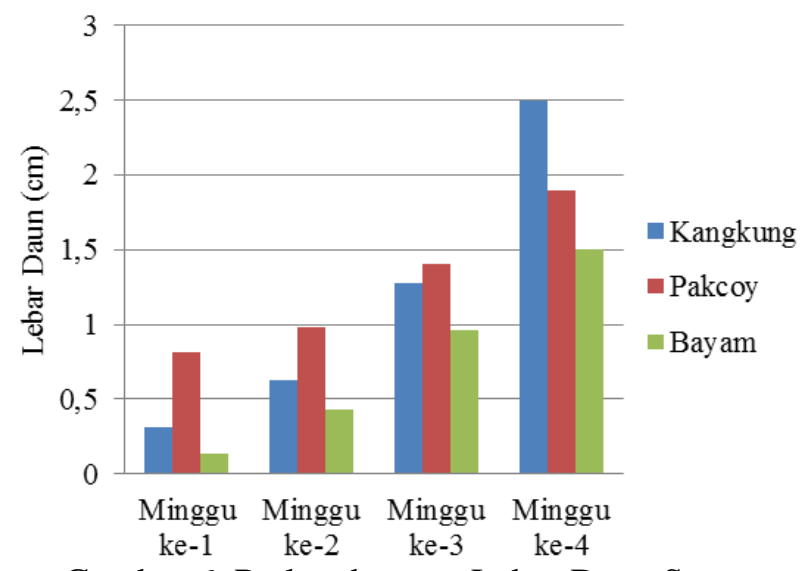

Gambar 6. Perkembangan Lebar Daun Sayur Kangkung, Pakcoy, dan Bayam

\section{Panjang daun}

Sebagaimana pada pengukuran-pengukuran sebelumnya, pengamatan panjang daun diukur mulai minggu pertama hingga minggu keempat. Secara umum semua jenis sayur memiliki peningkatan panjang daun dari mingu pertama hingga minggu keempat (Gambar 7).

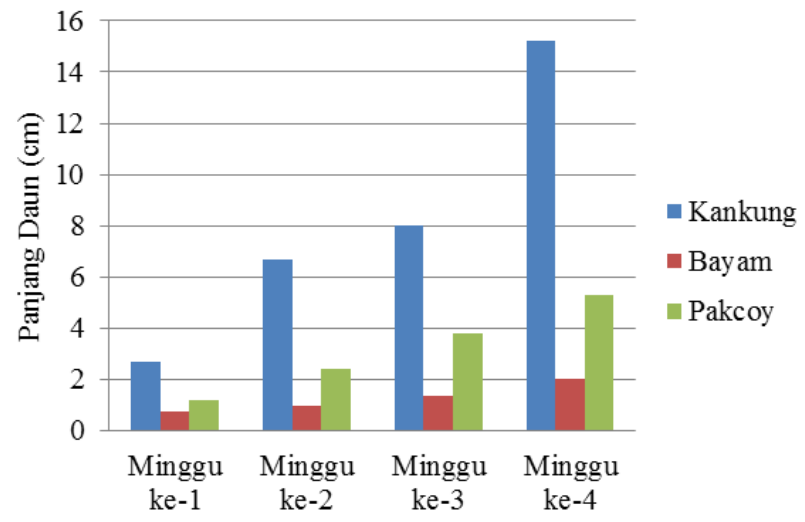

Gambar 7. Perkembangan Panjang Daun

5. Jumlah daun

Peningkatan tinggi tanaman dapat mendukung penambahan jumlah daun seiring bertambahnya umur tanaman. Artinya, semakin tinggi tanaman maka jumlah daun semakin banyak. Kangkung memiliki jumlah daun lebih banyak berkisar antara 18-21 helai (Gambar 8) dibandingkan dengan bayam 
dan pakcoy, dimana jumlah daun bayam berkisar antara 3-5 helai.

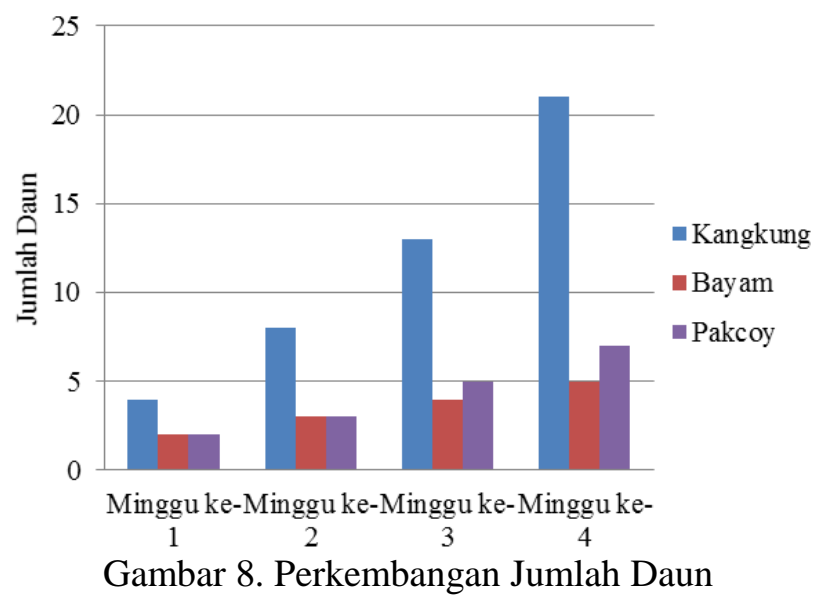

\section{KESIMPULAN}

Berdasarkan hasil penelitian dapat diambil beberapa kseimpulan sebagai berikut:

1. Pertumbuhan sayur kangkung terlihat lebih cepat dan lebih baik dibandingkan sayur pakcoy dan sayur bayam.

2. Tinggi sayuran dari minggu pertama hingga minggu keempat mengalami peningkatan, begitu juga dengan diameter batang, panjang daun, lebar daun, dan jumlah daun.

3. Peningkatan tinggi tanaman pada minggu keempat merupakan hasil dari pemberian dosis pupuk yang lebih tinggi dari kotoran ikan. Peningkatan ini terjadi karena pemberian nutrisi dapat meningkatkan kadar nitrogen yang dibutuhkan tanaman untuk pertumbuhanya.

4. Peningkatan tinggi tanaman dapat mendukung penambahan jumlah daun seiring bertambahnya umur tanaman. Artinya, semakin tinggi tanaman maka jumlah daun semakin banyak.

\section{DAFTAR PUSTAKA}

Budiati, E.T., (2017), Respon Pertumbuhan dan Hasil Tanaman Kangkung Darat (Ipomoea reptans P.) pada Media Tanaman Arang Sekam dan Cocopeat serta Konsentrasi POH Cair, Skripsi. Purwokerto: Universitas Muhamadiyah Purwekrto.

Furoidah, N., \& Wahyuni. S., (2017), Peningkatan Hasil Sayuran Lokal Kabupaten Limajang di Lahan Terbatas, AGRITEK: Jurnal Ilmu
Pertanian, Kehutanan dan Agroteknologi, Vol. 17, No. 2, hal. 7-20

Habiburrohman, (2018), Aplikasi Teknologi Akuaponik Sederhana pada Budidaya Ikan Air Tawar untuk Optimalisasi Pertumbuhan Tanaman Sawi, Skripsi. Lampungt: Universitas Islam Negeri Radenintan Lampung.

Hidayat. T., (2019), Respon Tanaman Kangkung darat Terhadap Kosentrasi Pupuk Organic Cair Nasa. Skripsi. Padang: Universitas Andalas Padang.

Khairuman, H \& Amri, K., (2013), Budidaya Ikan Nila, Jakarta Selatan: AgroMedia Pustaka

Sastro, Y., (2015), Akuaponik: Budidaya Tanaman Terintegrasi dengan Ikan, Permasalahan Keharaan dan Strategi Mengatasinya, Buletin Pertanian Perkotaan, Vol. 5, No. 1, hal. 3342.

Sarido. L., \& Junia, (2017), Uji Pertumbuhan dan Hasil Tanaman Sayuran dengan Pemberian Pupuk Organik Cair pada Sistem Hidroponik, Jurnal Teknologi Lingkungan, Vol. 16, No. 1, hal:65-74.

Setiawan. A., (2014), Budidaya Tanaman. Bogor: IPB.

Suyanto. R., (2010), Pembenihan dan Pembesaran Nila. Jakarta: Penebar Swadaya.

Tafajani. H., (2011), Panduan Komplit Bertanam Sayur dan Buah-buahan, Yogyakarta: Cahaya Atma. 